\title{
Analisis Faktor Penghambat TPACK Subdomain CK dan TPK pada Calon Guru Biologi UNNES
}

\author{
Rayi Uningal ${ }^{1}$, Talitha Widiatningrum ${ }^{2}$ \\ ${ }^{1,2}$ Universitas Negeri Semarang - Kampus Sekaran, Kelurahan Sekaran, Kecamatan \\ Gunungpati 50229
}

\begin{abstract}
Tujuan dari penelitian ini adalah untuk menganalisis dan mendeskripsikan keterlaksanaan praktek mengajar terkait CK dan TPK pada calon guru Biologi UNNES serta mengetahui faktor penghambat kemampuan CK dan TPK sebagai bagian dari kemampuan TPACK pada calon guru Biologi UNNES. Desain penelitian ini adalah deskriptif kuantitatif. Penelitian ini menggunakan instrumen angket Content Representation oleh Loughran et al. Hasil dari penelitian menunjukkan bahwa calon guru biologi UNNES angkatan 2016 banyak memilih materi pada kelas X dan kelas XI karena menganggap merupakan materi yang masih awal, materi dasar dengan tingkat kesulitan yang tidak terlalu besar. Calon guru biologi UNNES lebih menekankan pada penguasaan fakta dan konsep biologi serta kurang terlatih merencanakan pembelajaran biologi yang sesuai dengan hakekat sains. Media pembelajaran yang digunakan berupa media PPT serta melakukan penayangan video dan gambar. Akan tetapi, pemanfaat internet sebagai media belajar oleh calon guru biologi UNNES hanya sebesar 23,50\%. Calon guru biologi UNNES belum banyak memiliki pengalaman mengajar, sehingga merasa kurang percaya diri mengintegrasikan teknologi dalam pembelajaran. Kesimpulan dari penelitian ini yaitu calon guru biologi UNNES belum terbiasa untuk menggunakan Kata Kerja Operasional dalam pembuatan tujuan pembelajaran sehingga kurang mampu mengkomunikasikan tuntutan pembelajaran yang sesuai dengan hakekat sains dan kurangnya pengalaman dalam mengajar menyebabkan kurangnya kepercayaan diri dalam mengintegrasikan teknologi.
\end{abstract}

Kata kunci: TPACK, CK, TPK

\section{PENDAHULUAN}

Pendidikan di Indonesia sudah mengalami perubahan kurikulum setidaknya ada delapan Kurikulum Pendidikan yang pernah berlaku di Indonesia sejak kemerdekaan tahun 1945 Kurikulum tersebut adalah Rencana Pelajaran 1947, Rencana Pelajaran Terurai 1952, Kurikulum 1968, Kurikulum 1975, Kurikulum 1984, Kurikulum 1994 Dan Suplemen Kurikulum 1999, Kurikulum KBK 2004, Kurikulum KTSP 2006, dan kurikulum yang digunakan saat ini yaitu Kurikulum 2013. Sejauh ini, kurikulum 2013

Universitas Negeri Semarang

Email: rayiulala29@gmail.com
C2020 Universitas Islam Negeri Walisongo 132

ISSN: 2088-7868, e-ISSN 2502-5708 
merupakan kurikulum terbaik yang pernah dimiliki sekolah di Indonesia. Salah satu pertimbangan untuk sampai kepada kesimpulan tersebut, adalah mengenai elemen perubahan berupa tuntutan beberapa kompetensi yang harus dipenuhi pada kurikulum 2013 dibandingkan dengan kurikulum sebelumnya (Ibrahim, 2016). Rusilowati et al (2012) menyatakan bahwa calon guru perlu dibekali kemampuan mengajar dengan mengintegrasikan keterampilan-keterampilan yang dapat memberdayakan siswa.

Permendiknas Nomor 16 Tahun 2007, memberikan penjelasan secara umum mengenai empat kompetensi guru yaitu kompetensi pedagogi, professional, sosial dan personal. Dipertegas dalam PP Republik Indonesia No. 74 tahun 2008 pasal 2 ayat (2) yang menyebutkan, bahwa kompetensi guru meliputi kompetensi pedagogik, kompetensi kepribadian, kompetensi sosial dan kompetensi profesional yang diperoleh melalui pendidikan profesi. Pada ayat (4) dijelaskan, bahwa kompetensi pedagogik merupakan kemampuan guru dalam pengelolaan pembelajaran peserta didik, sedangkan pada ayat (7) dijelaskan, bahwa kompetensi profesional merupakan kemampuan guru dalam menguasai pengetahuan bidang ilmu pengetahuan, teknologi, dan/atau seni dan budaya yang diampunya. Shulman (1986) menyatakan atas dasar pentingnya kompetensi pedagogik dan profesional tersebut, maka muncul suatu pemahaman baru yakni Technological Pedagogical Content Knowledge (TPACK).

Berdasarkan hasil studi awal menggunakan angket TPACK yang dilakukan pada mahasiswa pendidikan biologi angkatan 2016 yang merupakan calon guru Biologi UNNES menunjukkan bahwa Skor rerata yang paling tinggi dari dasar pengetahuan inti (TK, PK, dan CK) adalah PK (pengetahuan pedagogik) dan yang paling rendah adalah CK (pengetahuan konten) sebesar 2,85. Sedangkan skor rerata tertinggi dari dasar pengetahuan inti kedua (TCK, TPK, dan PCK) adalah TCK dan yang paling rendah adalah TPK sebesar 2,87.

Pertimbangan bahwa kemajuan TPACK merupakan kemampuan yang wajib dimiliki oleh guru maka analisis kemampuan TPACK menjadi dasar yang penting dalam manajerial sekolah. Kemampuan TPACK guru atapun calon guru menjadi suatu hal yang perlu untuk dikaji lebih lanjut. Analisis TPACK ini tentunya tidak lepas dari faktor penghambat yang seharusnya dapat menjadi bahan pertimbangan sebagai titik poin perbaikan TPACK. Berdasarkan uraian latar belakang diatas perlu di teliti tentang faktor penghambat TPACK subdomain CK dan TPK pada calon guru biologi UNNES. Analisis 
TPACK dilakukan dengan memfokuskan pada dua sub pengetahuan atau subdomain meliputi pengetahuan konten (content knowledge) dan pengetahuan teknologi pedagogi (technological pedagogical knowledge).

\section{METODE PENELITIAN}

Penelitian ini dilaksanakan di Jurusan Biologi FMIPA UNNES pada bulan Januari - Juni 2019. Desain yang digunakan dalam penelitian ini adalah desain deskriptif kualitatif. Penelitian ini termasuk penelitian studi kasus yang akan dilakukan untuk melihat faktor penghambat kemampuan TPACK subdomain CK dan TPK pada calon guru biologi UNNES. Sample dalam penelitian ini adalah sebanyak 34 mahasiswa angkatan 2016 yang sedang melakukan praktek mengajar pada mata kuliah Microteaching.

Data dan metode pengambilan data yang digunakan dalam penelitian ini disajikan pada Tabel 1.

Tabel 1. Data dan Metode Pengambilan Data

\begin{tabular}{|c|c|c|c|c|}
\hline No & Jenis Data & $\begin{array}{c}\text { Teknik } \\
\text { Pengambilan } \\
\text { Data } \\
\end{array}$ & Sumber Data & $\begin{array}{c}\text { Waktu } \\
\text { Penelitian }\end{array}$ \\
\hline \multirow{3}{*}{1} & \multirow{3}{*}{$\begin{array}{l}\text { Keterlaksanaan } \\
\text { pembelajaran di kelas } \\
\text { terkait CK dan TPK }\end{array}$} & Observasi & \multirow{3}{*}{$\begin{array}{l}\text { Calon guru } \\
\text { biologi UNNES } \\
\text { angkatan } 2016\end{array}$} & \multirow{3}{*}{$\begin{array}{l}\text { Mei-Juni } \\
2019\end{array}$} \\
\hline & & Angket CoRe & & \\
\hline & & $\begin{array}{l}\text { Dokumentasi } \\
\text { RPP }\end{array}$ & & \\
\hline \multirow{3}{*}{2} & \multirow{3}{*}{$\begin{array}{l}\text { Faktor penghambat } \\
\text { terlaksananya } \\
\text { pembelajaran di kelas } \\
\text { terkait CK dan TPK }\end{array}$} & Observasi & \multirow{3}{*}{$\begin{array}{l}\text { Calon guru } \\
\text { biologi UNNES } \\
\text { angkatan } 2016\end{array}$} & \multirow{3}{*}{$\begin{array}{l}\text { Mei-Juni } \\
2019\end{array}$} \\
\hline & & Angket CoRe & & \\
\hline & & $\begin{array}{l}\text { Dokumentasi } \\
\text { RPP }\end{array}$ & & \\
\hline
\end{tabular}

Prosedur penelitian penelitian ini terdiri dari empat tahapan, yaitu tahap persiapan, pelaksanaan, analisis data dan pelaporan. Pada tahap persiapan dilakukan observasi awal melalui pengisian angket TPACK dengan calon guru biologi UNNES angkatan 2016 untuk menemukan permasalahan awal, menyusun rancangan penelitian, dan menyiapkan instrumen penelitian. Tahap pelaksanaan digunakan untuk memperoleh triangulasi data melalui angket CoRe, observasi dan dokumentasi RPP serta melakukan tambahan data melalui wawancara dengan calon guru biologi UNNES angkatan 2016. 


\section{HASIL DAN PEMBAHASAN}

\section{Kemampuan CK pada calon guru biologi UNNES}

Berdasarkan penelitian yang telah dilaksanakan dengan metode angket CoRe, observasi dan dokumentasi RPP, diperoleh data kemampuan calon guru biologi UNNES angkatan 2016 (34 orang dari 6 rombel). Data yang telah diperoleh kemudian dianalisis dan disajikan seperti berikut.

\section{Tabel 2 Kemampuan CK pada Calon Guru Biologi UNNES}

\begin{tabular}{ll}
\hline \multicolumn{1}{c}{ Sumber data } & \multicolumn{1}{c}{ Informasi } \\
\hline Angket Co-Re & $\begin{array}{l}\text { Jumlah ide besar untuk mengembangkan materi ajar ada 1 sampai } \\
5 .\end{array}$ \\
\hline Observasi & $\begin{array}{l}\text { Pada saat mengajar calon guru biologi kurang percaya diri, takut } \\
\text { dan masih ragu-ragu dalam menjelaskan materi. Calon guru masih } \\
\text { terlalu sering membaca PPT pada saat penyampaian materi }\end{array}$ \\
\hline $\begin{array}{l}\text { Dokumentasi } \\
\text { RPP }\end{array}$ & $\begin{array}{l}\text { Dikaji dari kata kerja operasional dalam tujuan pembelajarannya } \\
\text { maka fokusnya masih pada penguasaan konsep (domain kognitif } \\
\text { C1 dan C2) paling banyak adalah kata operasional menjelaskan } \\
\text { sebanyak 52,90\%. }\end{array}$ \\
\hline $\begin{array}{l}\text { Interprestasi data : Kemampuan CK calon guru biologi UNNES belum } \\
\text { maksimal }\end{array}$
\end{tabular}

Jumlah ide besar untuk mengembangkan materi ajar ada 1 sampai 5. Ide besar materi dapat menjadi dasar dalam penyusunan materi atau bahan ajar. Mahasiswa banyak memilih materi pada kelas X dan kelas XI karena menganggap merupakan materi yang masih awal, materi dasar dengan tingkat kesulitan yang tidak terlalu besar. Keluasan dan kedalaman materi ajar dapat dianalisis dari kompetensi, indikator pembelajaran, dan bahan ajar yang dikembangkan oleh guru (Sukaesih et al, 2017). Observasi pada calon guru biologi UNNES angkatan 2016 menunjukkan adanya rasa kurang percaya diri calon guru saat mengajar yakni tidak melihat kepada audience selama praktek mengajar.

Pada materi Sistem Ekskresi terdapat perbedaan jumlah ide besar yang diambil yakni M25 sebanyak 3 sedangkan M26 sebanyak 5. Hal tersebut dapat dipengaruhi oleh pengalaman mengajar yang dimiliki oleh calon guru biologi UNNES angkatan 2016. M26 diketahui sudah memiliki pengalaman mengajar sebagai tentor dalam les privat sehingga materi yang diajarkannya jauh lebih luas dan mendalam. Djamarah (1997) menyatakan bahwa pengalaman mengajar adalah salah satu aspek yang mempengaruhi kompetensi seorang guru di bidang pendidikan dan pengajaran. Kompetensi professional menyangkut 
penguasaan materi keilmuan yang sesuai dengan bidang studi yang diampu guru. Melalui pengalaman guru juga belajar mengembangkan dan memperbaiki diri menjadi lebih baik, karena sesuai dengan teori kontruktivisme belajar merupakan proses mengasimilasi dan menghubungkan pengalaman atau bahan yang dipelajarinya dengan pengertian yang sudah dimiliki, sehingga pengertiannya menjadi berkembang. Sehingga dengan pengalaman mengajar calon guru dapat meningkatkan pencapaian standar kompetensi professional guru.

Hasil rata-rata kemampuan mahasiswa calon guru dalam merumuskan Tujuan pembelajaran biologi adalah seperti tertera dalam gambar 1 .

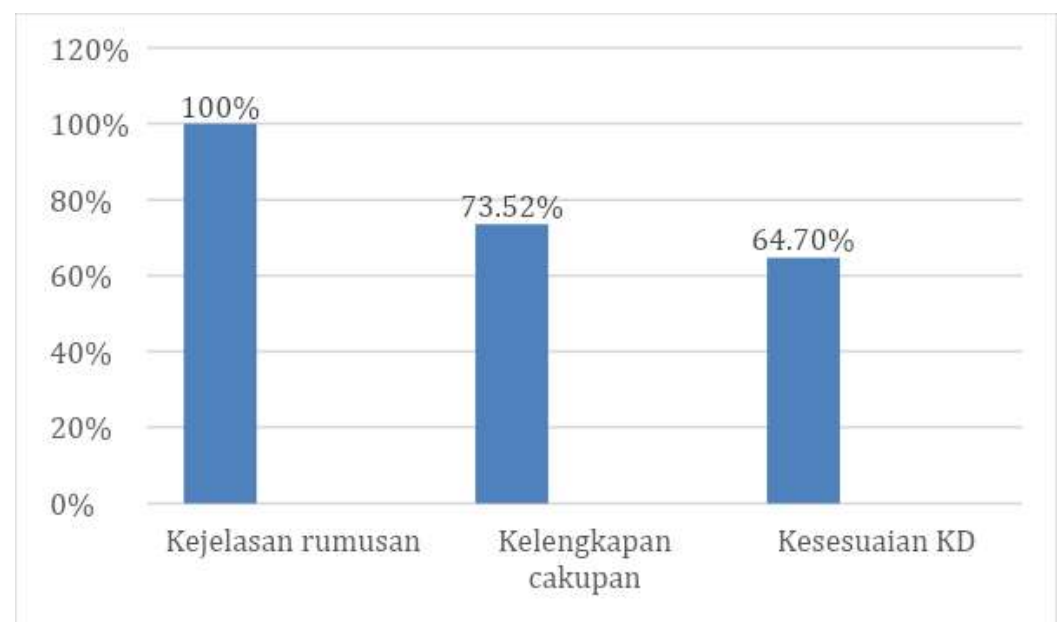

\section{Gambar 1 Kemampuan Calon Guru Biologi UNNES dalam Merumuskan Tujuan Pembelajaran}

Dari data tersebut dapat dinyatakan bahwa mahasiswa calon guru biologi sudah cukup mampu merumuskan Tujuan Pembelajaran namun masih memuat sedikit kegiatan belajar yang mengarah pada proses sains dan keterampilan berpikir tingkat tinggi. Jika dikaji dari kata kerja operasional dalam tujuan pembelajarannya maka fokusnya masih pada penguasaan konsep (domain kognitif $\mathrm{C} 1$ dan $\mathrm{C} 2$ ) paling banyak adalah kata operasional menjelaskan sebanyak 52,90\%, (lihat Gambar 1) 


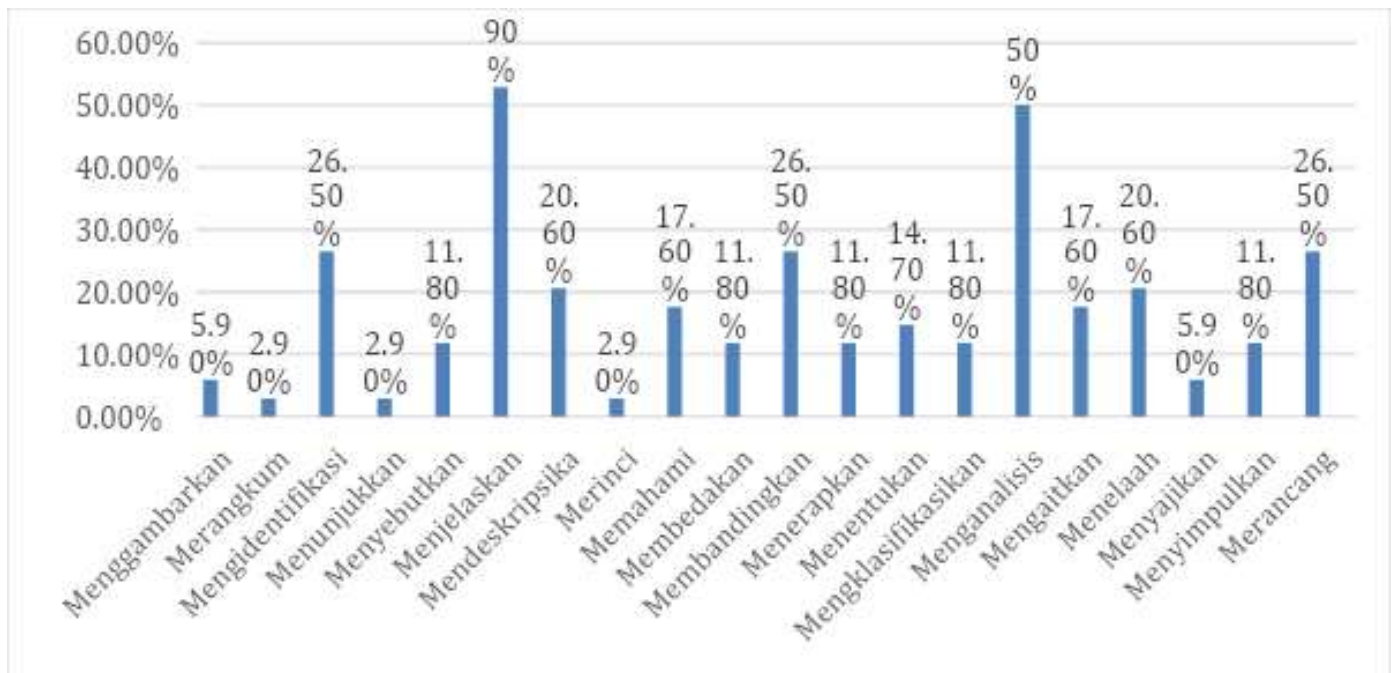

\section{Gambar 2 Penggunaan KKO pada Tujuan Pembelajaran Calon Guru Biologi UNNES}

Mahasiswa tidak terbiasa memasukkan kata kerja operasional yang bersifat active learning, kerja ilmiah atau keterampilan proses sains seperti kemampuan mengajukan/ merumuskan masalah, merumuskan hipotesis, mengamati, menganalisis, memecahkan masalah, mengambil keputusan, mengemukakan pendapat/gagasan, mengajukan pertanyaan. Hal ini di dukung dari hasil wawancara bahwa mahasiswa kurang terlatih untuk merumuskan dan menyusun perencanaan pembelajaran yang sesuai dengan hakekat sains.

Dengan penguasaan materi yang baik, guru bisa mengembangkan materi pada level yang lebih tinggi sehingga bisa menghadirkan pembelajaran yang lebih menantang. Penguasaan guru yang baik tentang materi pelajaran terutama yang berada pada level HOTS akan memicu siswa untuk terbiasa berfikir tingkat tinggi. Higher Order of Thinking Skill (HOTS) adalah kemampuan berpikir kritis, logis, reflektif, metakognitif, dan berpikir kreatif yang merupakan kemampuan berpikir tingkat tinggi. Kurikulum 2013 juga menuntut materi pembelajarannya sampai metakognitif yang mensyaratkan peserta didik mampu untuk memprediksi, mendesain, dan memperkirakan (Makhrus et al, 2019). Pembelajaran seperti ini menunjang pengembangan kecakapan abad 21.

\section{Kemampuan TPK calon guru Biologi UNNES}

Berdasarkan penelitian yang telah dilaksanakan dengan metode angket CoRe, observasi dan dokumentasi RPP, diperoleh data kemampuan calon guru biologi UNNES 
angkatan 2016 (34 orang dari 6 rombel). Data yang telah diperoleh kemudian dianalisis dan disajikan seperti berikut.

Tabel 3 Kemampuan TPK pada calon guru biologi UNNES

\begin{tabular}{ll}
\hline \multicolumn{1}{c}{ Sumber data } & \multicolumn{1}{c}{ Informasi } \\
\hline Angket Co-Re & $\begin{array}{l}\text { Calon guru biologi UNNES sudah menggunakan dan } \\
\text { memanfaatkan teknologi sebagai media belajar di kelas }\end{array}$ \\
\hline Observasi & $\begin{array}{l}\text { Calon guru biologi UNNES menyampaikan materi dengan bantuan } \\
\text { PPT sederhana dan mengambil video dari youtube sebagai media } \\
\text { belajar di kelas }\end{array}$ \\
\hline $\begin{array}{l}\text { Dokumentasi } \\
\text { RPP }\end{array}$ & $\begin{array}{l}\text { Sumber dan media belajar yang paling banyak digunakan yakni } \\
\text { buku dan PPT. }\end{array}$ \\
\hline $\begin{array}{l}\text { Interprestasi data : Calon guru biologi UNNES sudah memanfaat beberapa } \\
\text { teknologi yang sifatnya masih sederhana seperti PPT dan video }\end{array}$
\end{tabular}

Hasil analisis angket CoRe menggambarkan bahwa calon guru biologi UNNES sudah menggunakan dan memanfaatkan teknologi. Media belajar yang digunakan antara lain yaitu PPT, video, gambar dan media autentik. Video paling sering digunakan oleh calon guru biologi UNNES angkatan 2016 yakni sebesar 88,20\% dari jumlah sampel. Sedangkan yang paling jarang digunakan yakni media autentik sebesar 8,80\% dari jumlah sample. Kemampuan memilih materi yang sesuai dengan materi pembelajaran maupun yang sesuai dengan karakteristik peserta didik belum optimal, padahal untuk biologi banyak sekali specimen yang bisa dimanfaatkan baik yang segar maupun yang awetan. Jaringan tumbuhan dan Jaringan hewan sebenarnya dapat memanfaatkan preparat untuk dapat mengamati struktur penyusunnya tidak hanya melalui penayangan video dan gambar.

Observasi pada calon guru biologi UNNES angkatan 2016 menunjukkan bahwa mahasiswa menggunakan PPT, video dan gambar untuk membantu proses pembelajaran selama praktek mengajar. PPT yang digunakan cukup sederhana dan di dalamnya terdapat penyajian gambar yang digunakan untuk membantu calon guru selama penyampaian materi di kelas. Calon guru biologi UNNES memanfaatkan teknologi yang sudah ada yakni dengan mengambil video dari youtube sebagai bahan diskusi siswa di kelas.

Pemanfaat internet sebagai media belajar oleh calon guru biologi UNNES hanya sebesar 23,50\%. Dalam pemanfaatan fasiltas internet seperti media sosial, blog dan sebagainya untuk membantu pembelajaran masih kurang. Kondisi penghambat ini dikarenakan materi yang diajarkan sudah banyak terdapat dibuku cetak, sedangkan 
adanya pemanfaatan teknologi tambahan yang biasanya digunakan sebagai kondisi pendukung mengintegrasikan teknologi ke pembelajaran berupa pemanfaatan animasi dan video yang sudah di unduh terlebih dahulu terkait dengan pengetahuan Sains. Diharapkan, dengan memanfaatkan internet dalam pembelajaran akan menghasilkan inovasi pembelajaran yang membuat siswa lebih bergairah untuk belajar. Muhammad Yaumi (2011) menyatakan bahwa, penggunaan media komunikasi seperti internet telah membangun model interaksi baru dalam pembelajaran pada saat sekarang ini. Teknologi juga bisa memberi metode baru untuk mengajar yang memudahkan untuk diterapkan di kelas. Sebagai contoh munculnya online learning memerlukan guru untuk mengembangkan pendekatan pedagogis baru yang tepat. Guru harus kompeten dalam pengetahuan subjek, keterampilan pedagogis dan pengetahuan teknologi (Khine, et al., 2017).

Dokumentasi RPP menunjukkan bahwa sumber dan media belajar yang paling banyak digunakan adalah buku dan PPT sebesar 73,50\% dan 70,60\%. Sedangkan yang paling jarang digunakan yaitu lingkungan sekitar dan media autentik sebesar 14,70\% dan $17,70 \%$. Penggunaan internet dalam proses pembelajaran masih sangat kurang yakni hanya sebesar 23,50\% dari jumlah sampel. Melihat perbedaan media dan sumber belajar yang digunakan berdasarkan angket CoRe dan RPP dikarenakan mahasiswa harus mampu menyesuaikan alokasi waktu pada saat praktek mengajar yakni hanya 20-25 menit untuk setiap mahasiswa. Sehingga mau tidak mau selama praktek mengajar mahasiswa hanya menggunakan media yang sederhana demi tercapainya tujuan pembelajaran. Untuk penggunaan internet tidak dilakukan dalam pembelajaran mengingat tidak semua sekolah memiliki dan menyediakan koneksi internet yang memadai. Pada dasarnya mahasiswa sudah memliki kemampuan yang baik dalam penggunaan teknologi yang biasa digunakan dalam proses pembelajaran. Namun mahasiswa calon guru tidak terbiasa dalam mengintegrasikan pengetahuan tentang teknologi dalam proses pembelajaran. Calon guru biologi UNNES belum banyak memiliki pengalaman mengajar, sehingga wajar apabila mereka kurang percaya diri dalam mengintegrasikan teknologi dalam pembelajaran.

Keyakinan diri dalam mengintegrasikan teknologi disadari sebagai salah satu faktor yang mempengaruhi guru dalam memutuskan teknologi yang akan dipakai (Abitt, 2011). Adanya keyakinan diri mengintegrasikan teknologi akan membuka peluang seseorang untuk mencari pengalaman dengan mencoba pembelajaran yang mengintegrasikan 
beragam jenis teknologi. Individu akan cenderung memilih tugas dan kegiatan yang mana mereka merasa kompeten dan percaya diri dan menghindari tugas dan kegiatan yang mereka tidak bisa (Pajares, 2002). Kesuksesan atau keberhasilan dalam menggunakan teknologi sangat ditunjang dari dalam diri guru, bahkan menjadi faktor utama yang sangat berpengaruh (Wang et al. 2004). Pengembangan teknologi ini menjadi sesuatu yang mutlak mengingat perkembangan teknologi informasi yang begitu pesat dan cepat.

\section{SIMPULAN}

Berdasarkan hasil dan pembahasan dapat disimpulkan bahwa Calon guru biologi UNNES belum terbiasa untuk menggunakan Kata Kerja Operasional dalam pembuatan tujuan pembelajaran sehingga kurang mampu mengkomunikasikan tuntutan pembelajaran yang sesuai dengan hakekat sains dan kurangnya pengalaman dalam mengajar menyebabkan kurangnya kepercayaan diri dalam mengintegrasikan teknologi.

\section{DAFTAR PUSTAKA}

Abbitt, J.T. 2011. An Investigation of the Relationship between Sefl-Efficacy Beliefs about Technology Integration and Technological Pedagogical Content Knowledge (TPACK) among Preservice Teacher. Journal Digital Learning in Teacher Education, 27(4): 134-143.

Djamrah, Syaiful Bahri, dan Aswin Zain.1997.Strategi Belajar Mengajar. Jakarta: Rineka Cipta

Ibrahim, M. 2016. Pembelajaran Sains di Sekolah Dasar Berbasis Kurikulum 2013. Premiere Educandum: Jurnal Pendidikan Dasar dan Pembelajaran, 4(01).

Khine, M. S., Ali, N. \& Afari, E. (2017). Exploring relationships among TPACK constructs and ICT achievement among trainee teachers. Education and Information Technologies. Volume 22, Issue 4, pp 1605-1621.

Makhrus, M., Harjono, A., Syukur, A., Bahri, S., \& Muntari, M. (2019). Identifikasi Kesiapan LKPD Guru Terhadap Keterampilan Abad 21 Pada Pembelajaran IPA SMP. Jurnal Ilmiah Profesi pendidikan, 3(2).

Pajares, F. 2002. Overview of Social Cognitive Theory and of Self-Efficacy. Tersedia di http://www.uky.edu/ eushe2/Pajares/eff.html [diakses 4-8- 2019].

Rusilowati, A., Hartono, Supriyadi. 2012. Pengembangan Model Pembelajaran Better Teaching and Learning Berkarakter untuk Membekali Kompetensi Pedagogi Mahasiswa Calon Guru. Jurnal Penelitian Pendidikan.Vol.29 No.2 Hal.83- 92. Semarang: LP2M Unnes

Shulman, L. S. 1986. Those who understand: Knowledge growth in teaching. Educational researcher, 15(2), 4-14.

Sukaesih, S., Ridlo, S., \& Saptono, S. (2017). Profil Kemampuan Pedagogical Content Knowledge (PCK) Calon Guru Biologi. Lembaran Ilmu Kependidikan, 46(2), 6874. 
Wang L., P.A. Ertmer, dan T.J. Newby. 2004. Increasing Preservice Teacher's SelfEfficacy Beliefs for Technology Integration. Journal Research on Technology in Education, 36(3): 231-250.

Yaumi, M. (2011). Integrasi Teknologi Informasi dan Komunikasi dalam Pembelajaran. Lentera Pendidikan, 6(108), 1017-1054. 